\title{
Smart Strategy: Intelligence, Gaming and Agility
}

\author{
Simon Huston \\ UQ Business School, The University of Queensland, St Lucia Campus, Brisbane QLD 4072, Australia
}

\begin{abstract}
Generals, entrepreneurs and planners aim to dislocate enemies, outsmart competitors or build iconic cities. All advocate 'smart strategy' but what are its constituents? I seek some cross-disciplinary clarification. A selection of military, business and planning literature is investigated, looking for common themes and a smart strategy framework. Strategic complexity and the limits to generalisation in turbulent times are noted. In the military, overwhelming force confronts asymmetric warfare with deception and carefully-calibrated power projections, conducted at tempo, to confuse and overwhelm the enemy. In business, making money is necessary but insufficient for a smart strategy. Other 'smart' criteria are ethics, delegation, talented people and continuous systems innovation. In urban planning, centralist or dispersed intervention strategies jostle with evolutionary ones but without a final resolution in complex, idiosyncratic cities with adjustment lags and spatial irresolution. Despite context dependency, our multi-disciplinary overview generates some practical business advice. A smart strategy recoils from top-down, techno-centric or managerialist litanies. Clarity of purpose, sound intelligence and judgment orientate the entity and harmonize its activities around key products/markets. Deception confuses and disorientates competitors but needs product support. Flexibility/adaptability balances informed leadership with devolved innovation, underpinned by systems upgrades and talent.
\end{abstract}

Keywords: Strategy, Military, Business, Urban Planning, Intelligence, Foresight, Gaming, Agility

\section{INTRODUCTION}

Simplistic notions of 'smart strategy' are wrong because organizations have competing objectives, confront complex turbulent environments with information asymmetry (Whittington, 2001; Osinga, 2007; George, 2011). The word 'smart' is widely applied. Generals use 'smart bombs', academics and government advocate for various 'smart responses to global warming' (Lomborg, 2010; Rayner, 2007). Other smart applications extend to power grids (Joskow, 2012), computing (Alamouti, 1998), genetics (Schultz et al., 1998) and cities (Caragliu et al., 2009). Smart rhetoric, though, can mask corporate fraud or stupidity (Shiller, 2005; Alvesson, 2010). The paper looks for a common conceptual thread to link together military, business and planning discourse. The goal is a general framework for smart strategy and some practical business recommendations.

\subsection{Smart Military Strategy}

Warfare is a destructive rather than constructive activity (Bungay, 2011) but military discourse could, nevertheless, yield some insights for smart strategy, particularly in regards to business competition although scrutiny of military practice is, perhaps, less useful for planners. Tzu (2000) is a seminal military text. It certainly dispels static strategic notions and notes that tactics without strategy is 'the noise before defeat'. Famously, Sun Tzu also states: 'all warfare is based on deception' (ibid: 1.18), a point often neglected in conventional business texts. For Sun Tzu, the ingredients for victory are competent commanders, an ideological consensus or 'Moral Law' and robust intelligence and logistic systems or 'Method' to inform position ('Earth'), determine timing ('Heaven') and execute audaciously.

In European antiquity, Marathon was a key battle. Greeks won the day by a bold sortie from Athens which 
allowed them to surprise one part of the divided Persian army (Billows, 2010). In the Roman era, Scipio Africanus seized the initiative both when he marched on New Carthage and when he invaded Africa. Scipio had a firm grasp of the broad situation, formulated bold plans which he executed flexibly. His preparations were thorough and extended to strengthening the moral of his troops. He also modernized the Roman Army (Gabriel, 2008), although, contrary to popular myth, Scipio did not instigate the adoption of the infamous Spanish gladius (Hackett, 1989).

In late antiquity, continuous reflection on strategy and military adaptation in the face of new threats, such as Hunnic composite bow, explain Byzantine's endurance (Luttwak, 2009). In Strategikon, for example, the Emperor Maurice (circa 592 AD) dissects engagements, such as the Battle of Dara in 530 AD. Here, General Belisarius used intelligence, surprise and 'flexibility under unified effort and leadership' to cement victory (Dornstadter, 2010). According to Hughes (2009), at Dara Belisarius 'engineered events so that the main enemy strike would occur on the flanks' which deliberately recoiled to enable a lateral counter-attack. Belisarius's used topography, defensive trenches and capitalized on Persian mistakes (Lillington-Martin, 2007).

In the nineteenth century, Napoleon distilled military strategy into 'a well-reasoned and extremely circumspect defensive, followed by a rapid and audacious attack'. The commander's unflappable judgment was critical but, Boyd notes, with time, Napoleonic battles, such as at Borodino (1812), became more static and destructive (Osinga, 2007). Clausewitz (2008) overtly advocated for attrition warfare. His wunderliche dreifaltigkeit or 'holy trinity of war' (ibid 19) was violence, chance and rational calculation aimed at destruction. Given the difficulty of filtering 'false from true information' (ibid: 149) in the fog of war, the prosecution of an innovative attack is inevitably risky. Technological and logistical system superiority helps mitigate risk. Telegraph and rail dominance gave Union troops eventual victory in the American Civil War (Cohen, 1996). Deception or 'gaming' is an alternate way to moderate risk. The Soviets used Maskirovka to deliver force 'preponderance at the decisive point' (ibid: 156) and unhinged the Germans both at Stalingrad in November 1942 and Kursk the following year.

In recent times, the setbacks, expense and public relations disasters entailed in asymmetric conflicts in Iraq and Afghanistan catalyzed re-thinking of US military strategy. Nowadays, the emphasis is more on subversion, disorientation and disruption to 'get inside the adversary's OODA (Observation, orientation, decision and action) loops', overload systems, destroy harmony and shatter the 'will to resist' (Osinga, 2007: 176). Flexible use of multiple tools, including soft power and unconventional war degrades an enemy's capacity to act (Davis et al., 1996; Lloyd, 2011; Ojiako et al., 2010; Nye, 2004). The 2008 US Military Field Manual now extends to information management and includes cyberspace as part of battlefield 'situational awareness'.

\subsection{Smart Business Strategy}

In conventional business strategy, 'observation' and 'orientation' are merged into one step: 'establishing position' (Johnson and Scholes, 2008). The potency of traditional management and financial tools to inform strategy diminishes as technological and other 'unstructured randomness' or turbulence increases (Ansoff, 1965; Robbins, 1987; Mintzberg, 1994). Traditional investment appraisal discounting techniques struggle to evaluate project viability (Borison, 2005; Caldwell et al., 2006; Luehrman, 1998; Mitchell, 2009; Mun, 2006; Taleb, 2010). Despite these well-established limitations, populist and other business literature proffers a bewildering and, in the end, superficial spectrum of practical strategic 'solutions' across a swathe of areas (Melnyk et al., 2010). Whittington (2001) offers deeper insight into 'smart strategy' beyond superficial classical frameworks or fragmented corporate practices. $\mathrm{He}$ proposes four strategic approaches: 'classical', 'evolutionary', 'processualists' and 'systemic' with a spectrum of outcomes and implementation mechanisms. Clearly, the pre-requisite for a smart business strategy is clarification of purpose, time horizon and risk appetite.

However, in commerce, just as in war, victory alone is insufficient. A smart commercial strategy must both generate adequate returns for risk and also meet other deontological and teleological criteria. Cost-cutting or gaming is insufficient. Plagued by parochial attitudes, petty politicking and agency problems, conservative or 'comprador' firms can yet be profitable. 'Dumb' profits can be earnt by milking 'cash cow' products, compromising safety, exploiting subsidies, polluting or by paying bribes and kickbacks. Product usefulness/quality is questionable in comprador entities. Staff is de-motivated and team learning is ineffective (Geus, 1988). Such entities are cunning but not smart. A smart business, on the other hand, delivers a quality product with some collective benefits. Like a general, concentrating his forces behind a deceptive veil of skirmishers, a smart business delivers a productive blow 
under its marketing hype. Clever marketing can build initial awareness, but, ultimately, must support a socially-useful product. Lack of product authenticity, dilutes trust and increases long-term risk (Beer and Eisenstat, 1996; Philp, 2012). Strong governance and audit capabilities help to detect transactions which, although ostensibly lucrative, are unethical, have delayed or dispersed cost implications. Here, the dismal record of Tepco, BP and many banks during the Global Financial Crisis bear witness (GW, 2010).

Ethical leadership underpins smart commercial strategy. Clear purpose, risk posture and ethics nurture an the entrepreneurial and productive culture required for an authentically smart strategy which balances foresight with subsidiarity (delegation). Proactive human resource management builds a climate of innovative delegation and Entrepreneurial Orientation (EO). Committed smart people automatically follow leading trends, talk to experts and early adopters (Hertz, 2011) and generate the artful scenarios which inform firm adaptation (Heijden, 2011). Apart from ethical and intelligent, a smart entity continuously adapts. It re-configures its architecture, alliances and systems to upgrade intelligence and productive capabilities. Intelligence updates extend to customers, competitors and various risks beyond the diminished 'flatland' of scanning around current operations (Bartlet and Ghoshal, 1993; McShane and Glinow, 2008).

Even some collaborative research consortia recoil from deep strategic synthesis or strategic foresight to question 'currently popular ideology' (Slaughter, 1999). In contrast, Wilber (1996) internal/external and individual/collective quadrants provide an Integral Futures (IF) conceptual framework to scan beyond the compromised implicit acceptance of dominant social structures and cultural perspectives. Unlike incremental forecasting and scenario analysis, strategy Informed by (IF) goes 'beyond the collapse of industrialism' (Slaughter, 2004). Causal Layered Analysis (CLA) is another IF tool to explore different epistemologies beneath the surface gloss of popular litany. It unwraps reality by exposing underlying assumptions, neglected systemic causes and cultural baggage implicit in uncritically accepted 'worldviews' or myths (Riedy, 2008).

In short, the literature on business strategy reveals a contested and fragmented landscape with a gulf separating comprador or conservative from and smart entrepreneurial firms. Impoverished by an entirely pragmatic mindset, the former group pursues short-term returns and lacks foresight. Instead, comprador or conservative firms sell tried and tested product or protect existing market share by gaming the current dysfunctional system. Gaming extends to a spectrum of socially degenerative activities including bribery, counterfeiting, mimicking, lobbying, dissimulating, deceiving or monopoly practices. In contrast, smart EO firms prosecute nimble and authentic commercial pathways, geared on nurturing enduring trust in an evolving circular economy with products designed for recycling and distributed across mixed real and virtual channels.

\subsection{Smart Strategy in Urban Planning}

Strategy in urban planning is also contested. First, the legitimate sphere of government intervention is disputed. The ideological dispute between interventionists and libertarians ruptures urban planning. For interventionists 'smart strategy' sketches inspiring collective betterment visions, directs unhealthy private impulses and curtails opportunistic excesses. Libertarians, on the other hand, question the legitimacy, opportunity costs and unintended consequences of imposed urban objectives and resist any restraint. For interventionists, manifest 'market failure' impels strategic direction toward 'community good' (Aristotle, 2006). Harmony is impossible unless private architectural, environmental or aesthetic excesses are resolutely curbed. However, planners dispute the functional direction, form or even the best mechanism to achieve lofty urban social objectives. Some seek to impose monumental engineering or architectural solutions to enhance global competitiveness or attract investment. Others recoil from the foisting of autocratic or bureaucratic 'corporate machine-architecture' and, instead, favor democratization and devolved planning regimes for community health (Alexander, 2010).

Most planned settlements were built for religious or defensive purposes while the complex layered pattern of organic ones emerged in Europe over centuries from the conflicted pursuit of hegemony, contingent geography and evolving trade patterns (Nicholas et al., 2003). Roman urban planners either had religious, military or symbolic agendas to reinforce the Emperor's power through spectacle or centralized monumentalism. In De Architectura (circa 40 BC), the Roman planner, Vitruvius, dwells on shading and aeration for amphitheatres to diffuse the smell of evisceration (Hall, 2002) while Augustus extended the architectural legitimization of his regime by revitalizing Rome's vici or neighborhoods (Lott, 2004). In medieval Europe, many cities consolidated a Roman nucleus but, disease, 
conflict or migration mitigated their subsequent development. In the Umayyad capital of Cordoba, for example, prolonged sieges hemmed Syrian refugees within its walls and explain its current dense urban morphology (Hillenbrand, 1999).

In the modern era, Haussmann's Paris, Le Corbusier grandiose master plans or Lutyen's colonial New Delhi, dismissed by Pevsner and Aitchison (2010) as pastiche historicism, all illustrate strong centralist tendencies and symbolic domination. Ebenezer Howard offers another collective but, this time, more decentralized alternative to the 'sordid congestion' of English towns. He proposed the democratic dispersal of the 'Garden City' (Howard, 2008). For Howard, rail was the physical key to intelligent dispersal but real urban progress required the social betterment and a 'greater regard for the well being of our fellows' (Howard, 2008). Howard blamed urban failure on both a 'want of foresight of those who little dreamed of the future development of the railways?' and 'a society largely based on selfishness and rapacity' (ibid: 211).

For Sir Patrick Geddes (1949) smart urban strategy has a 'neotechnic' orientation beyond the obsessive obfuscation of 'money economics'. Rather than the 'private dissipation of resources' smart neotechnic strategy is informed by a 'vital synoptic vision' for 'public conservation' and to connect 'the past with detailed multifaceted assessment of current assets' (ibid: 142). For Geddes, grandiose monumentalism treats the symptoms of urban isolation whereas the 'conservative surgery' of piecemeal rehabilitation cures it. Fordlandia in Brazil provides a salutary, if exotic, illustration of the dangers of excessive autocratic monumentalism (Grandin, 2010).

Financial turmoil, manifest waste and injustice notwithstanding (Shleifer, 2000), libertarians dogmatically resist autocratic centripetal or dispersed attempts to impose betterment. The default consequence, with a globalized economy, is that international capital flows and consequent job migration drive chaotic urban change. India presents a good example with sub-national and local planning regimes ineffective in moderating transformation of Bangalore, Kolkata and Delhi by information technology firms (Chatterji, 2011). In the liberal discourse, the Internet and social media have revolutionized the urban planning landscape and governments, rather than attempting to modify the urban fabric, should instead let or even facilitate the operation of market forces (Ratti and Townsend, 2011).

In the climate, a 'politics of urgency' though has popularized a gamut of 'strategic solutions across a spectrum of technocratic or community poles with 'smart' labels. New Sondago city, in Korea, or Masdar
City, in the United Arab Emirates, are, respectively, technocratic 'knowledge' or ostensibly 'green' imposed strategic ones but perhaps a wiser path toward real sustainable creative cities is more people-orientated development (Goede, 2011; O'Connor and Healy, 2004; Rooney and McKenna, 2005; Throsby, 2006).

\section{CONCLUSION}

To conclude the eclectic foray into urban planning looking for smart strategy again encountered a severely conflicted landscape. Strategic urban planning pits utopians, with their disparate collective urban visions, against libertarians protesting against waste or managerialism (Wadley, 2008). Libertarian 'cyborg' cities overtly or implicitly support existing social structure, vested commercial interests without adequate responses to collective challenges (Gandy, 2005; Gleeson, 2010; Newman et al., 2009; Rybczynski, 2011). Unmanaged populations, climate change, peak oil, pollution, congestion and unprecedented extinctions, seem to calls for collective intervention. But, because urban systems are idiosyncratic, complex and strongly influenced by spatially remote policy or global turbulence (Heywood, 1969), no definitive planning blueprint is forthcoming. Nevertheless while smart urban detail is unresolved, it is underpinned by informed judgment, rule of law and robust governance.

\subsection{Synthesis: Proposed Smart Strategy Framework}

The, albeit eclectic, conspectus of strategy across the military, business and planning disciplines encounters discord and no singular framework for 'smart' strategy. In military sphere, litanies of 'overwhelming force' contrast with a panoply of forces, shaping and reconfiguration for adaptability. In business, much conventional strategy has a diminished problem-solving and practical stance, compromised by implicit acceptance of dominant ideology, social structures or cultures. To my mind, a 'smart' business must make clean money intelligently. Others may disagree but, here, I exclude comprador or conservative strategic stances without collective merit, innovation or ethical constraints. In planning, libertarians resist collective impositions, whether autocratic or inspired by place-making for community dwelling. However, the legacy of laissez-faire planning regimes is often dystopic. Dysfunctional manifestations include slums, insidious sprawl, congestion, toxicity and the proliferation of ugliness. 
In an uncertain and complex world, characterised by diverse objectives and different cultural, legal and administrative backdrops, survival depends on ingenuity and adaptation. Surprise military campaigns, innovative products or catalyst urban renewal projects are executed promptly and cost-effectively. In the event of setbacks, smart strategy adapts to either resilient pursuit or rapid disengagement and redeployment of assets. Smart strategy provokes deeper questioning of short-term orientations and dominant cognitive representations, assumptions and existing practices. Practical business advice from our multidisciplinary conspectus includes:

- Clarify entity purpose and risk appetite

- Tap into multiple intelligence sources

- Use foresight techniques to seize the initiative

- Build team harmony and by authentic and ethical leadership

- Collaborate with trusted partners

- Diversify projects portfolio across a spectrum of risk

- Recognise the tension between compliance (governance) and adaptability (delegation)

- Gain feedback from suppliers and customer to for product quality/innovation

- Use deception to mislead competitors

- Encourage systems evolution for resilience

- Adopt continuous learning

- Recruit and nurture talent

\section{REFERENCES}

Alamouti, S.M., 1998. A simple transmit diversity technique for wireless communications. IEEE J. Selected Areas Commun., 16: 1451-1458. DOI: $10.1109 / 49.730453$

Alexander, M.J., 2010. Gravity Waves in the Stratosphere. Geophys. Monogr. Ser., 190: 109-121. DOI: 10.1029/2009GM000887

Alvesson, M., 2010. A stupidity-based theory of the firm. University of Queensland Business School, Brisbane.

Ansoff, H.I., 1965. Corporate Strategy: An Analytic Approach to Business Policy for Growth and Expansion. 1st Edn., McGraw-Hill, pp: 241.

Aristotle, W.E., 2006. Politics. 1st Edn., Echo Library, Middlesex, ISBN-10: 1406806684, pp: 184.

Bartlet, C.A. and S. Ghoshal, 1993. Beyond strategic planning to organization learning: Lifeblood of the individualized corporation. Strategy Leadership, 26: 34-39. DOI: $10.1108 / \mathrm{eb} 054610$
Beer, M. and R.A. Eisenstat, 1996. Developing an organization capable of implementing strategy and learning. Hum. Relat., 49: 597-619. DOI: $10.1177 / 001872679604900504$

Billows, R.A., 2010. Marathon: The Battle that Changed Western Civilization. 1st Edn., Duckworth Publishers, New York, ISBN-10: 0715639080, pp: 352.

Borison, A., 2005. Real options analysis: Where are the emperor's clothes? J. Applied Corporate Finance, 17: 17-31. DOI: 10.1111/j.1745-6622.2005.00029.x

Bungay, S., 2011. How to make the most of your company's strategy. Harvard Bus. Rev.

Caldwell, B., S. Aldington, M. Weatherall, P. Shirtcliffe and R. Beasley, 2006. Risk of cardiovascular events and celecoxib: A systematic review and metaanalysis. J. R Soc. Med., 99: 132-140. PMID: 16508052

Caragliu, A., C.D. Bo and P. Nijkamp, 2009. Smart cities in Europe. Proceedings of the 3rd Central European Conference in Regional Science, (CERS' 09), Slovak Republic, Kosice, pp: 45-59.

Chatterji, 2011. Impact of globalisation at the peri-urban interface of Indian Cities: Emerging information technology clusters and comparative planning cultures. The University of Queensland, Brisbane.

Clausewitz, C.V., 2008. On War: Vom Kriege. 1st Edn., Forgotten Books, ISBN-10: 1606800884, pp: 300.

Cohen, E.A., 1996. A revolution in warfare. Foreign Aff., 75: 37-54.

Davis, P.K., D. Gompert and R. Kugler, 1996. Adaptiveness in National Defense: The Basis of a New Framework. 1st Edn., Rand, Santa Monica, Calif., pp: 11.

Dornstadter, A.J., 2010. Battle of Dara. Engineer.

Gabriel, R.A., 2008. Scipio Africanus: Rome's Greatest General. 1st Edn., Potomac Books, Inc., Washington, D.C., ISBN-10: 1597972053, pp: 303.

Gandy, M., 2005. Cyborg urbanization: Complexity and monstrosity in the contemporary city. Int. J. Urban Regional Res., 29: 26-49. DOI: 10.1111/j.14682427.2005.00568.x

Geddes, P., 1949. Cities in Evolution. 1st Edn., Williams and Norgate, London, pp: 241.

George, B.A., 2011. Entrepreneurial orientation: A theoretical and empirical examination of the consequences of differing construct representations. J. Manage. Stud., 48: 1291-1313. DOI: 10.1111/j.1467-6486.2010.01004.x 
Geus, D., 1988. Planning as Learning. 1st Edn., Harvard Business School Reprint, Boston, MA., ISBN-10: $000088202 X$, pp: 6.

Gleeson, B., 2010. The greatest spoiler. Griffith Rev.

Goede, M., 2011. The wise society: Beyond the knowledge economy. Foresight, 13: 36-45. DOI: 10.1108/14636681111109688

Grandin, G., 2010. Fordlandia: The Rise and Fall of Henry Ford's Forgotten Jungle City. 1st Edn., Metropolitan Books, New York, ISBN-10: 0312429622 , pp: 432.

GW, 2010, International thief. The Complicity of British Banks in Nigerian Corruption.

Hackett, S.J.W., 1989. Warfare in the Ancient World. 1st Edn., Sidgwick and Jackson, London, ISBN-10: 0283995912, pp: 256.

Hall, P.G., 2002. Cities of Tomorrow: An Intellectual History of Urban Planning and Design in the Twentieth Century. 3rd Edn., Wiley-Blackwell, Malden, Mass., ISBN-10: 0631232648, pp: 553.

Heijden, K.V.D., 2011. Scenarios: The Art of Strategic Conversation. 2nd Edn., John Wiley and Sons, Chichester, UK., ISBN-10: 1119995523, pp: 380.

Hertz, N., 2011. How to use experts-and when not to. TED Conference.

Heywood, P.R., 1969. Plangloss: A critique of permissive planning. Town Plann. Rev., 40: 251262.

Hillenbrand, R., 1999. Islamic Art and Architecture. 1st Edn., Thames and Hudson, London, ISBN-10: 0500203059, pp: 288.

Howard, E.G., 2008. Garden Cities of Tomorrow. 1st Edn., Forgotten Books, ISBN-10: 1606201867, pp: 150 .

Hughes, I., 2009. Belisarius: The Last Roman General. 1st Edn., Pen and Sword Military, Barnsley, ISBN10: 1844158330 , pp: 272.

Johnson, G. and K. Scholes, 2008. Exploring Corporate Strategy: Text and Cases. 7th Edn., Pearson Education India, Harlow, ISBN-10: 8131719251, pp: 1072 .

Joskow, P.L., 2012. Creating a smarter U.S. electricity grid. J. Econ. Perspectives, 26: 29-47. DOI: 10.1257/jep.26.1.29

Lillington-Martin, C., 2007. Archaeological and Ancient Literary Evidence for a Battlenear Dara Gap, Turkey, AD 530: Topography, Texts and Trenches. The Late Roman Army in the East.
Lloyd, J., 2011. Secret society. Financial Times.

Lomborg, B., 2010. Smart Solutions to Climate Change: Comparing Costs and Benefits. 1st Edn., Cambridge University Press, Cambridge, ISBN-10: 0521138566, pp: 413.

Lott, J.B., 2004. The Neighborhoods of Augustan Rome. 1st Edn., Cambridge University Press, New York, ISBN-10: 0521828279, pp: 262.

Luehrman, T.A., 1998. Strategy as a Portfolio of Real Options. 1st Edn., Harvard Business Review, pp: 11.

Luttwak, E., 2009. The grand strategy of the Byzantine Empire. 1st Edn., Harvard University Press, Cambridge MA., ISBN-10: 0674035194, pp: 498.

McShane, S. and M.V. Glinow, 2008. Organizational Behavior: Essentials. McGraw-Hill/Irwin, Boston, ISBN-10: 0073381225, pp: 424.

Melnyk, S.A., J.D. Hanson and R.J. Calantone, 2010. Hitting the target but missing the point: Resolving the paradox of strategic transition. Long Range Plann., 43: 555-574. DOI: 10.1016/j.lrp.2009.11.004

Mintzberg, H., 1994. Fall and Rise of Strategic Planning. 1st Edn., Harvard Business School Reprint, ISBN10: 0000941077.

Mitchell, S.D., 2009. Unsimple Truths: Science, Complexity and Policy. 1st Edn., University of Chicago Press, Chicago, ISBN-10: 0226532623, pp: 149.

Mun, J., 2006. Real Options Analysis: Tools and Techniques for Valuing Strategic Investments and Decisions. 2nd Edn., John Wiley and Sons, Hoboken, New Jersey, ISBN-10: 0471747483, pp: 667.

Newman, P., T. Beatley and H. Boyer, 2009. Resilient Cities: Responding to Peak Oil and Climate Change. 1st Edn., Island Press, Washington, D.C., ISBN-10: 1597264997, pp: 166.

Nicholas, R.S., J. Partridge, R.P. Donn, C. Hawkins and M.D. Boggild, 2003. The role of the PTPRC (CD45) mutation in the development of multiple sclerosis in the North West region of the United Kingdom. J. Neurol. Neurosurg. Psychiatry, 74: 944-945. PMID: 12810785

Nye, J.S., 2004. Soft Power: The Means to Success in World Politics. 1st Edn., Public Affairs, New York, pp: 191.

O'Connor, K. and E. Healy, 2004. Rethinking suburban development in Australia: A Melbourne case study. Eur. Plann. Stud., 12: 27-40. DOI: $10.1080 / 09654310310001635698$ 
Ojiako, U., J. Johnson, M. Chipulu and A. Marshall, 2010. Unconventional competition-drawing lessons from the military. Prometheus: Critical Stud. Innovat., 28: 327-342. DOI: 10.1080/08109028.2010.541756

Osinga, F.P.B. 2007. Science, Strategy and War: The Strategic Theory of John Boyd. 1st Edn., Routledge, Abingdon, ISBN-10: 0203088867, pp: 336.

Pevsner, N. and M. Aitchison, 2010. Visual Planning and the Picturesque. 1st Edn., Getty Publications, Los Angeles, ISBN-10: 1606060015, pp: 221.

Philp, B., 2012. Consumer Republic: Using Brands to Get What you Want, Make Corporations Behave and Maybe Even Save the World. 1st Edn., McClelland and Stewart, Toronto, ISBN-10: 0771070047, pp: 274.

Ratti, C. and A. Townsend, 2011. The social nexus. Sci. Am., 305: 42-48. DOI: 10.1038/scientificamerican0911-42

Rayner, M., 2007. Smart Cities: Rethinking the City Centre. 1st Edn., Smart State Council, Brisbane, pp: 37.

Riedy, C., 2008. An integral extension of causal layered analysis. Futures, 40: 150-159. DOI: 10.1016/j.futures.2007.11.009

Robbins, S.P., 1987. Organization Theory: Structure, Design and Applications. 1st Edn., Prentice-Hall, Englewood Cliffs, ISBN-10: 0136421822, pp: 518.

Rooney, D. and B. McKenna, 2005. Should the knowledge-based economy be a savant or a sage? Wisdom and socially intelligent innovation. Prometheus: Critical Stud. Innovat., 23: 307-323. DOI: $10.1080 / 08109020500211025$

Rybczynski, W., 2011. Makeshift Metropolis: Ideas About Cities. 1st Edn., Scribner, New York, ISBN10: 1416561269 , pp: 256.

Schultz, J., F. Milpetz, P. Bork and C.P. Ponting, 1998. SMART, a simple modular architecture research tool: Identification of signaling domains. Proc. Nat. Acad. Sci. USA., 95: 5857-5864.
Shiller, R.J., 2005. Irrational Exuberance. 2nd Edn., Princeton University Press, Princeton, N.J., ISBN10: 0691123357, pp: 304.

Shleifer, A., 2000. Inefficient Markets: An Introduction to Behavioral Finance. 1st Edn., Oxford University Press, Oxford, ISBN-10: 0191606898, pp: 224.

Slaughter, R.A., 1999. A new framework for environmental scanning. Foresight, 1: 441-451. DOI: $10.1108 / 14636689910802331$

Slaughter, R.A., 2004. Futures Beyond Dystopia: Creating Social Foresight. 1st Edn., Routledge, London and New York, ISBN-10: 0415302692, pp: 306.

Taleb, N.N., 2010. The Black Swan: The Impact of the Highly Improbable. 2nd Edn., Random House Trade Paperbacks, New York, ISBN-10: 081297381X, pp: 480.

Throsby, D., 2006. The Economics of the Creative City: Iconic Architecture and the Urban Experience. In: Talking about Sydney: Population, Community and Culture in Contemporary Sydney, Freestone, B. Randolph and C. Butler-Bowdon (Eds.), University of New South Wales Press, Sydney, ISBN-10: 0868409383, pp: 149-161.

Tzu, S., 2000. The Art of War. 1st Edn., Mundus Publishing, pp: 99.

Wadley, D., 2008. The garden of peace. Ann. Assoc. Am. Geographers, 98: 650-685. DOI: $10.1080 / 00045600802099162$

Whittington, R., 2001. What is Strategy and Does it Matter? 2nd Edn., Cengage Learning EMEA, London, ISBN-10: 1861523777, pp: 151.

Wilber, K., 1996. A Brief History of Everything. 1st Edn., Shambhala Publications, Boston, ISBN-10: $157062187 X$, pp: 339. 